\title{
CALLUS INDUCTION AND BIOMASS ACCUMULATION IN VITRO IN EXPLANTS FROM CHOKEBERRY (Aronia melanocarpa (Michx.) Elliot) FRUIT
}

\author{
${ }^{1}$ T. Calalb, ${ }^{1}$ A. Nistreanu, ${ }^{2}$ S. Oroian, ${ }^{2}$ M. Samarghitan \\ ${ }^{1}$ Public Institution of State Medicine and Pharmacy University "Nicolae Testemitanu" in Chisinau \\ ${ }^{2}$ Medicine and Pharmacy University Targu Mures \\ Chisinau, Malina Mica 66, Moldova \\ e-mail: tatianacalalb@yahoo.com
}

Received: 23.01.2014

\begin{abstract}
In this study, the following features were determined: biological (the optimal histogen as explant and the optimal age of donor fruit), biotechnological (type, dosage and combination of growth regulators supplements in culture medium Murashige and Skoog as well as sucrose dosage), and physical (light regime), to induce callusing and biomass accumulation in vitro from the succulent chokeberry (Aronia melanocarpa (Michx.) Elliot) fruit. It turned out that it was much easier to induce callus from explants composed of the epicarp and hypoderm cut from fruits at 50-60 days after flowering. The role of light regime and varied supplementation of the basic MS medium with different doses of growth regulators was established; they resulted in four pigmented carpomass: violet, cream-pink, cream-white and green. The best combinations for the proliferation of fruit callus were culture media with $0.2-2.5 \mathrm{mg} \times$ $\mathrm{dm}^{-3} 2,4-\mathrm{D}+0.5 \mathrm{mg} \times \mathrm{dm}^{-3} \mathrm{KIN}+60 \mathrm{~g} \times \mathrm{dm}^{-3}$ sucrose, while for fruit biomass accumulation enriched with phenolic substances $2.5-3.5 \mathrm{mg} \times \mathrm{dm}^{-3} \mathrm{NAA}+0.5 \mathrm{mg} \times \mathrm{dm}^{-3} \mathrm{KIN}+60 \mathrm{~g} \times \mathrm{dm}^{-3} \mathrm{su}-$ crose. The chemical study of phenolic compounds by HPLC coupled with the mass spectrometry method identified chlorogenic acid, hiperozide, quercetrin, isoquercitrin and rutozide quantitatively and qualitatively in all pigmented carpomass and fruits; an exception is p-coumaric present only qualitatively in green carpomass and absent in fruit and quercetol absent in green carpomass.
\end{abstract}

Key words: Fruits, Aronia melanocarpa, histology, callus, biomass, in vitro, phenolic compounds

\section{INTRODUCTION}

At the beginning of the third millennium, the interest in Aronia melanocarpa (Michx.) Elliot fruits has increased thanks to their content of phenolics, vi- tamins, organic acids, minerals, and carbohydrates [1-3]. Its fruits serve as a valuable source of biological active substances with pharmaceutical therapeutic virtues: vasoprotective, hypotensive [4], antioxidant [5], antimutagenic, chemopreventive, gastroprotective, antiviral, hypoglycaemic, anti-inflammatory, and antimicrobial $[2,3,6]$. Today, there is a demand for chokeberry fruits in the world market as a quality and antioxidant product; they supplement the daily food intake necessary to strengthen the body and are called "super fruits" [2,3].

A. melanocarpa is a native plant of North America and because of the decorative and curative qualities of its fruit it is grown on large areas in Asian and European countries, including the Republic of Moldova where various forest plantations occupy an area of 157.8 ha [7]. It is not always possible to pick good quality fruit in large amounts for various reasons observed in recent decades: frequent extreme weather events (frost and cold rains during flowering, drought, heat waves during the long summer period of fruit ripening), pollution (acid rains, gas emissions, harmful elements), which all have a negative effect on plant biology; lengthy and costly seasonal management practices for pest control and crop protection; difficulties with collection, transportation and storage. These impediments can be removed by applying in vitro culture microtechnology, with obvious advantages: independence of ecological-climatic factors and seasonal rotation, possibility of using physical and chemical factors, production proportions, continuous controlled environmental conditions, and direct cotroling accumulation of useful metabolites, reducing the risk of contamination by effective isolation 
of pathogens, and purification of useful compounds. Biomass obtained in vitro can serve as source material for traditional alternative materials in alimentary, culinary and pharmaceutical industries [7-9].

Scientific papers on induction of in vitro cultures, especially from succulent fruits, are scarce [7,9]. Fruits perform many functions, including the perpetuation of the species, and possess a certain level of selfadjustment and relative autonomy, keep extramaternal vitality for a long time thanks to the accumulation of trophic reserves, one of the specific features formed during the evolution [7-10], and require complex studies (especially succulent fruits) of their involvement in in vitro culture. Hence, the objective of the present study was to elucidate the biological, chemical and physical criteria for biotechnological strategies in induction and accumulation of in vitro carpomass of $A$. melanocarpa succulent fruits.

\section{MATERIALS AND METHODS}

Chokeberry (Aronia melanocarpa (Michx.) Elliot) fruits, at different ontomorphogenetic phases, from the collections of the Botanical Garden (Institute) of the Moldova Academy of Sciences and the Centre of Cultivation of Medicinal Plants of the State University of Medicine and Pharmacy "Nicolae Testemitanu" of the Republic of Moldova served as the source of explants. Pieces $(0.5 \mathrm{~cm} \times 0.5 \mathrm{~cm})$ of four pericarp histogens (epicarp; epicarp with hypoderm; external subzone of oval-rounded cells of mesocarp; internal subzone of oval-rounded cells of mesocarp and endocarp) sampled $10,20,30,40,50,60$ and 70 days after flowering to mature chokeberry fruits were used as explants. The explants were sterilized for 10-15 minutes in 1.0-1.5\% hypochlorite, then rinsed three times in sterile distilled water and inoculated aseptically on semisolid culture media Murashige Skoog with the following inorganic components $\left(\mathrm{mg} \times \mathrm{dm}^{-3}\right): \mathrm{NH}_{4} \mathrm{NO}_{3}-1650, \mathrm{KNO}_{3}-1900$, $\mathrm{MgSO}_{4} \times 7 \mathrm{H}_{2} \mathrm{O}-370, \mathrm{KH}_{2} \mathrm{PO}_{4}-170, \mathrm{CaCl}_{2} \cdot 2 \mathrm{H} 2 \mathrm{O}-$ $440, \mathrm{H}_{3} \mathrm{BO}_{3}-6.2, \mathrm{MnSO}_{4} \cdot 4 \mathrm{H} 20-223, \mathrm{CoCl}_{2} 6 \mathrm{H}_{2} \mathrm{O}$ $-0,025, \mathrm{CuSO}_{4} \cdot 5 \mathrm{H}_{2} \mathrm{O}-0.025, \mathrm{ZnSO}_{4}-7 \mathrm{H}_{2} \mathrm{O}-8.6$, $\mathrm{Na}_{2} \mathrm{MoO}_{4} \times 2 \mathrm{H}_{2} \mathrm{O}-0.25, \mathrm{KI}-0.83, \mathrm{FeSO}_{4} \times 7 \mathrm{H}_{2} \mathrm{O}$ $-27.8, \mathrm{Na}_{2}$ EDTA-37.3, at pH 5.8. The incubation temperature of $24^{\circ} \pm \mathrm{C} 2^{\circ} \mathrm{C}$ was maintained with complete darkness for good callus initiation for four days, then at 18/6h dark/light photoperiod for callus proliferation. Friable white and soft textured initial callus, formed especially at the cut ends of explants, was used for the following inoculations in different nutritive and light regimes. The basic Murashige Skoog media was supplemented with combinations of cytokinin $-0.5 \mathrm{mg} \times \mathrm{dm}^{-3}$ Kinetin (KIN) or $0.5 \mathrm{mg} \times \mathrm{dm}^{-3}$ of 6-Benzylaminopurine (BAP) and different doses of auxin $-1.0-4.0 \mathrm{mg} \times \mathrm{dm}^{-3}$ of Naphthalene acetic acid (NAA) or 1.0-4.0 $\mathrm{mg} \times \mathrm{dm}^{-3}$ of 2,4-dichlorophenoxyacetic acid (2,4-D) growth regulators. We tested 28 growth regulator variants of supplemented culture medium and each variant with 6 doses $\left(10-60 \mathrm{~g} \mathrm{dm}^{-3}\right)$ of sucrose - a total of 168 nutritive variants. 14 nutritive variants of growth regulator combinations were selected for callus proliferation: $7-0.5 \mathrm{mg} \times$ $\mathrm{dm}^{-3} \mathrm{KIN}, 1.0-4.0 \mathrm{mg} \times \mathrm{dm}^{-3}$ of NAA plus $60 \mathrm{~g} \times \mathrm{dm}^{-3}$ of sucrose; 7-0.5 mg $\times \mathrm{dm}^{-3} \mathrm{KIN}, 1.0-4.0 \mathrm{mg} \times \mathrm{dm}^{-3}$ of 2,4-D and $60 \mathrm{~g} \times \mathrm{dm}^{-3}$ of sucrose. $350 \mathrm{~cm}^{3}$ culture flasks, containing $30 \mathrm{ml}$ of culture medium, were used for tissue culture inoculations. Subcultures were done every four weeks by transferring the obtained callus mass onto fresh culture media of the same composition. Inoculated callus on selected 14 nutritive variants were maintained at $24^{\circ} \pm \mathrm{C} 2^{\circ} \mathrm{C}$ and in the following light regimes: natural photoperiod $16 / 8 \mathrm{~h}$; continuous light with an intensity of $40-70 \mu \mathrm{M} \cdot \mathrm{m}^{-2} \cdot \mathrm{s}^{-1}$; ultraviolet $-30 \mu \mathrm{M} \cdot \mathrm{m}^{-2} \cdot \mathrm{s}^{-1}$ and infrared $-80 \mu \mathrm{M} \cdot \mathrm{m}^{-2} \cdot \mathrm{s}^{-1}$.

For the determination of the callus growth index, fresh and dry weights were measured. The initial weight of inoculums was about $30 \mathrm{mg}$ fresh weight and $2 \mathrm{mg}$ dry weight. The callus mass was harvested after five weeks and the final fresh weight and dry weight were determined. The growth index was calculated: final dry weight - initial dry weight/initial dry weight. The experiments were repeated three times for three successive subcultivations.

Histo-anatomical investigations of chokeberry pericarp fruit were performed on thin cross sections using an optical microscope (Micros, Austria). Callus mass was analyzed for a set of features (color, consistence, direction of growth, surface relief, etc.) under a stereoscopic binocular loupe (MBR-10, Russia). Total polyphenols were determined by the Folin- Ciocalteu method and were expressed as mg of Gallic acid equivalents (GAE) per $\mathrm{kg}$ of fruits. The data presented are mean \pm standard deviation [11]. For identification and assay of phenolic compounds in the analyzed extracts of chokeberry fruits and pigmented (violet, cream-pink, cream-white and green) carpomasses, we used HPLC-MS modified method [12].

\section{RESULTS}

\section{Histological zonality of chokeberry pericarp}

Succulent fruits of Aronia melanocarpa (Michx.) Elliot belong to the carpotype pommum with specific histo-anatomical traits and phenolic metabolism. Therefore special precautions and individual biomicrotechnology was required at the cell, tissue and organ levels.

On cross section of chokeberry fruit pericarp, three histological zones were evidenced: epicarp, mesocarp (differentiated into 4 subzones: 1 - hypoderm; 2 - external subzone of oval-rounded cells; 
3 - subzone of radial oval-elongated cells; 4 - internal subzone of oval-rounded cells) and endocarp, which is formed at the initial phases and stabilizes during the

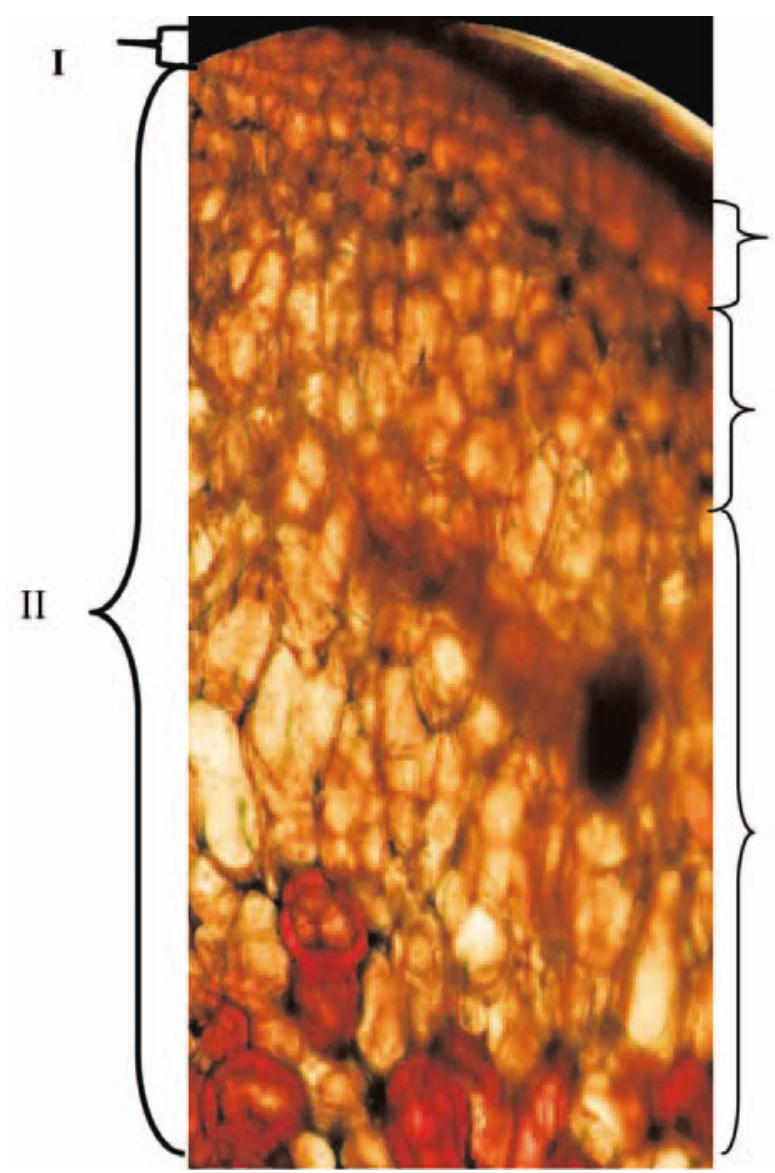

ontomorphogenesis period. The histological zonality of A. melanocarpa fruit pericarp 50 days after flowering is presented in Figure 1.

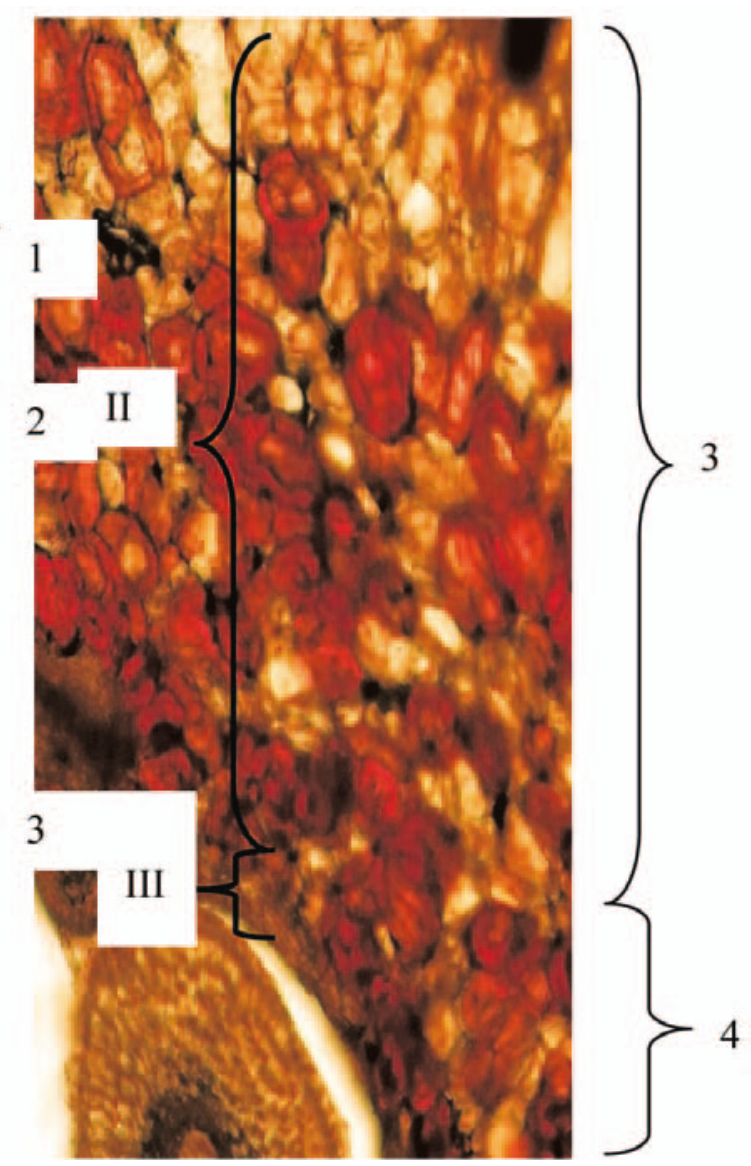

Fig. 1. Cross section of Aronia melanocarpa pericarp fruit: I - epicarp; II - mesocarp; III - endocarp, x300: 1 - hypoderm; 2 - external subzone of oval-rounded cells; 3 - subzone of radial oval-elongated cells; 4 - internal subzone of oval-rounded cells.

\section{Effect of donor-fruit age and explant type}

To determine the optimal age of the donor organ as explants, the histological nature of explants, and the explant position in relation to culture medium for inducing callogenesis and biomass accumulation in vitro, microscopic investigations were carried out.

The type of explants and the age of donor fruit were determined by tapping placing various histogens (epicarp; epicarp with hypoderm; external subzone of oval-rounded cells of mesocarp and internal subzone of oval-rounded cells of mesocarp with endocarp) from the period of 10-70 days after flowering to mature fruit on culture media with different combinations of growth regulators and different dosage of sucrose (Table 1). To identify the location of phenolic accumulation, histological analyses were done by applying specific reagents (solution of $2 \% \mathrm{AlCl}_{3}$ or solution of $10 \% \mathrm{NaOH}$ in ethanol) to the thin sections. Phenolic inclusions were observed around the cell wall and ton- oplast of small vacuoles in the cells of all histological zones of juvenile fruits (10-40 days after flowering). Beginning from 50 days after flowering until mature fruits, the parenchyma cells of mesocarp become larger and larger and many small vacuoles form one large vacuole by fusing, which serve as the main deposit for phenolic accumulations.

The explants (all histogens) cut from the juvenile fruit (10-40 days after flowering) inoculated on culture medium necrosed after five days. Necrosis also affected fruit explants collected after 70 days from flowering to maturity. Only explants consisting of epicarp and hypoderm taken from fruit at 50-60 days after flowering possess proliferative qualities, but the intensity of callusing correlates with the combination of growth regulators in culture media and the ontogenetic phase of fruit development. The histogens at 50 days demonstrated the highest intensity of callusing (excellent) and those at 60 days after flowering one 
degree less (very good) on medium with $0.5 \mathrm{mg} \times \mathrm{dm}^{-3}$ $\mathrm{KIN}+1.0-4.0 \mathrm{mg} \times \mathrm{dm}^{-3} 2,4-\mathrm{D}$. For all histogens cut from fruit at 50-60 days after flowering, the intensity of callusing was the same - it was good on medium supplemented with the combination of $0.5 \mathrm{mg} \times \mathrm{dm}^{-3}$ $\mathrm{KIN}+1.0-4.0 \mathrm{mg} \times \mathrm{dm}^{-3} \mathrm{NAA}$.

Table 1

Reactivity of Aronia melanocarpa (Michx.) Elliot fruit explants and intensity of callusing by age of donor organ, type of histogen, combination of growth regulators and dosage of sucrose

\begin{tabular}{|c|c|c|c|c|c|}
\hline $\begin{array}{l}\text { Age of donor } \\
\text { fruit (days after } \\
\text { flowering) }\end{array}$ & $\begin{array}{l}\text { Type of } \\
\text { histogen }\end{array}$ & $\begin{array}{l}\text { Combination of growth regulators } \\
\qquad\left(\mathrm{mg} \times \mathrm{dm}^{-3}\right)\end{array}$ & $\begin{array}{l}\text { Sucrose } \\
\left(\mathrm{g} \times \mathrm{dm}^{-3}\right)\end{array}$ & $\begin{array}{l}\text { Intensity of } \\
\text { callusing }\end{array}$ & Explant reactivity \\
\hline \multirow{4}{*}{$10-40$} & \multirow{4}{*}{$\begin{array}{l}\text { All } \\
\text { histogens }\end{array}$} & $0.5 \mathrm{BAP}+1.0-5.0 \mathrm{NAA}$ & $10-60$ & - & Necrosis \\
\hline & & $0.5 \mathrm{BAP}+1.0-5.02,4-\mathrm{D}$ & $10-60$ & - & Necrosis \\
\hline & & $0.5 \mathrm{KIN}$ and $1.0-5.0 \mathrm{NAA}$ & $10-60$ & - & Necrosis \\
\hline & & $0.5 \mathrm{KIN}$ and $1.0-5.0$ 2,4-D & $10-60$ & - & Necrosis \\
\hline \multirow{16}{*}{50} & Epicarp & $0.5 \mathrm{BAP}$ and $1.0-5.0 \mathrm{NAA}$ & $10-60$ & - & \multirow{4}{*}{$\begin{array}{c}\text { Necrosis } \\
\text { Translucent islets } \\
\text { Necrosis } \\
\text { Necrosis }\end{array}$} \\
\hline & Epicarp* & $0.5 \mathrm{BAP}$ and $1.0-5.0 \mathrm{NAA}$ & 60 & + & \\
\hline & Mesocarp* & $0.5 \mathrm{BAP}$ and $1.0-5.0 \mathrm{NAA}$ & $10-60$ & - & \\
\hline & Endocarp* & $0.5 \mathrm{BAP}$ and $1.0-5.0 \mathrm{NAA}$ & $10-60$ & - & \\
\hline & Epicarp & 0.5 BAP and 1.0-5.0 2,4-D & $10-60$ & - & \multirow{4}{*}{$\begin{array}{c}\text { Necrosis } \\
\text { Translucent islets } \\
\text { Necrosis } \\
\text { Necrosis }\end{array}$} \\
\hline & Epicarp* & $0.5 \mathrm{BAP}$ and $1.0-5.02,4-\mathrm{D}$ & 60 & + & \\
\hline & Mesocarp* & 0.5 BAP and 1.0-5.0 2,4-D & $10-60$ & - & \\
\hline & Endocarp* & $0.5 \mathrm{BAP}$ and $1.0-5.02,4-\mathrm{D}$ & $10-60$ & - & \\
\hline & Epicarp & $0.5 \mathrm{KIN}$ and 1.0-5.0 2,4-D; & 60 & ++ & \multirow{4}{*}{$\begin{array}{l}\text { Incipient, translucent callus. } \\
\text { Green and soft callus. } \\
\text { Necrosis } \\
\text { Necrosis }\end{array}$} \\
\hline & Epicarp* & $0.5 \mathrm{KIN}$ and $1.0-5.02,4-\mathrm{D}$ & 60 & +++++ & \\
\hline & Mesocarp* & $0.5 \mathrm{KIN}$ and $1.0-5.02,4-\mathrm{D}$ & $10-60$ & - & \\
\hline & Endocarp* & $0.5 \mathrm{KIN}$ and $1.0-5.02,4-\mathrm{D}$ & $10-60$ & - & \\
\hline & Epicarp & $0.5 \mathrm{KIN}$ and $1.0-5.0 \mathrm{NAA}$ & 60 & + & \multirow{4}{*}{$\begin{array}{c}\text { Incipient, translucid callus } \\
\text { Violet and viable callus. } \\
\text { Necrosis } \\
\text { Necrosis }\end{array}$} \\
\hline & Epicarp* & $0.5 \mathrm{KIN}$ and $1.0-5.0 \mathrm{NAA}$ & 60 & +++ & \\
\hline & Mesocarp* & $0.5 \mathrm{KIN}$ and $1.0-5.0 \mathrm{NAA}$ & $10-60$ & - & \\
\hline & Endocarp* & $0.5 \mathrm{KIN}$ and $1.0-5.0 \mathrm{NAA}$ & $10-60$ & - & \\
\hline \multirow{10}{*}{60} & All & $0.5 \mathrm{BAP}$ and $1.0-5.0 \mathrm{NAA}$ & $10-60$ & - & Necrosis \\
\hline & histogens & $0.5 \mathrm{BAP}$ and $1.0-5.02,4-\mathrm{D}$ & $10-60$ & - & Necrosis \\
\hline & Epicarp & $0.5 \mathrm{KIN}$ and $1.0-5.02,4-\mathrm{D}$ & 60 & ++ & \multirow{4}{*}{$\begin{array}{c}\text { Incipient, translucent callus. } \\
\text { Green and viable callus. } \\
\text { Necrosis } \\
\text { Necrosis }\end{array}$} \\
\hline & Epicarp* & $0.5 \mathrm{KIN}$ and $1.0-5.02,4-\mathrm{D}$ & 60 & ++++ & \\
\hline & Mesocarp* & $0.5 \mathrm{KIN}$ and $1.0-5.02,4-\mathrm{D}$ & $10-60$ & - & \\
\hline & Endocarp* & $0.5 \mathrm{KIN}$ and $1.0-5.02,4-\mathrm{D}$ & $10-60$ & - & \\
\hline & Epicarp & $0.5 \mathrm{KIN}$ and $1.0-5.0 \mathrm{NAA}$ & 60 & + & \multirow{4}{*}{$\begin{array}{c}\text { Incipient, non-viable callus } \\
\text { Violet and viable callus } \\
\text { Necrosis } \\
\text { Necrosis }\end{array}$} \\
\hline & Epicarp* & $0.5 \mathrm{KIN}$ and $1.0-5.0 \mathrm{NAA}$ & 60 & +++ & \\
\hline & Mesocarp* & $0.5 \mathrm{KIN}$ and $1.0-5.0 \mathrm{NAA}$ & $10-60$ & - & \\
\hline & Endocarp* & $0.5 \mathrm{KIN}$ and $1.0-5.0 \mathrm{NAA}$ & $10-60$ & - & \\
\hline \multirow{4}{*}{$\begin{array}{l}70 \text { days - } \\
\text { mature fruits }\end{array}$} & \multirow{4}{*}{ All histogens } & $0.5 \mathrm{BAP}$ and $1.0-5.0 \mathrm{NAA}$ & $10-60$ & - & \multirow{4}{*}{$\begin{array}{l}\text { Culture medium turns } \\
\text { pink and callus, necrosis }\end{array}$} \\
\hline & & 0.5 BAP and 1.0-5.0 2,4-D & $10-60$ & - & \\
\hline & & $0.5 \mathrm{KIN}$ and $1.0-5.0 \mathrm{NAA}$ & $10-60$ & - & \\
\hline & & $0.5 \mathrm{KIN}$ and $1.0-5.0$ 2,4-D & $10-60$ & - & \\
\hline
\end{tabular}

Legend: Epicarp*- epicarp with hypoderm; mesocarp* - external subzone of oval-rounded cells, endocarp* - endocarp with internal subzone of oval-rounded cells; Grading of callusing intensity: + poor; ++ relative; +++ good $;++++$ very good; +++++ excellent.

The inoculated explants had different histogens in contact with culture medium: epicarp, hypoderm, parenchyma of mesocarp, and endocarp. The examination made under a binocular loupe showed that the reaction of explants correlates with the type of histogen which is in contact with media. The analysis of the obtained results showed that only the hypoderm in contact with culture media had proliferative potency in vitro and generated new cells. The progressive callus induction was observed on the hypodermic lateral sides of the explant incisions, but callusing from the inside side of the explants was reduced by the mechanical strength of the medium, so proliferation prevailed on the lateral incisions, favoring horizontal biomass accumulation. 


\section{Effect of growth regulators and sucrose}

To initiate callusing and biomass accumulation in vitro, it is important to select an appropriate balance of growth regulators. 168 nutritive variants based on different doses of auxin (2,4-D or NAA) and cytokinin (KIN or BAP) were tried (explored). The observations and analyses permit us to select 14 combinations of growth regulators for explants consisting of epicarp and hypoderm from fruits aged 50 days after flowering for which the callus growth index was more than $45 \%$ (Table 2). It was found that explants which grew on media with $\mathrm{KIN}+2,4-\mathrm{D}$ combinations had higher values of the growth index (53.6-78.8\%) than those inoculated on the media with KIN+NAA $(45.8-64.3 \%)$. The medium concentrations of 2,4D $\left(1.5-3.0 \mathrm{mg} \times \mathrm{dm}^{-3}\right)$ stimulated the growth index $(72.2-78.8 \%)$, but the lower $\left(1.0-2.0 \mathrm{mg} \times \mathrm{dm}^{-3}\right)$ and higher (3.5-4.0 $\mathrm{mg} \times \mathrm{dm}^{-3}$ ) ones was disadvantageous. The highest callus growth index was obtained in the case of $2.5 \mathrm{mg} \times \mathrm{dm}^{-3}$ of 2.4-D. A lower callus growth index was determined for the combination of $0.5 \mathrm{mg} \times$ $\mathrm{dm}^{-3} \mathrm{KIN}+1-2 \mathrm{mg} \times \mathrm{dm}^{-3} \mathrm{NAA}$. The doses of $0.5 \mathrm{mg}$ $\times \mathrm{dm}^{-3} \mathrm{KIN}+3.0-3.5 \mathrm{mg} \times \mathrm{dm}^{-3}$ NAA demonstrated that this combination of growth regulators was most efficient for callus growth (64.3 and 62.4\%, respectively).

Table 2

Effect of growth regulator combinations on the callus growth index and callus color

\begin{tabular}{|c|c|c|c|c|c|}
\hline $\begin{array}{l}\text { Age of donor } \\
\text { fruit (days after } \\
\text { flowering) }\end{array}$ & Explant & $\begin{array}{l}\text { Combination of growth regulators } \\
\qquad\left(\mathrm{mg} \times \mathrm{dm}^{-3}\right)\end{array}$ & $\begin{array}{l}\text { Sucrose } \\
\left(\mathrm{g} \times \mathrm{dm}^{-3}\right)\end{array}$ & $\begin{array}{c}\text { Growth } \\
\text { index } \\
(\%)\end{array}$ & Callus color \\
\hline \multirow{14}{*}{50} & \multirow{7}{*}{$\begin{array}{l}\text { Epicarp } \\
\text { and hypoderm }\end{array}$} & $0.5 \mathrm{KIN}+1.02,4-\mathrm{D}$ & 60 & $53.6 \pm 2.9$ & Pale green \\
\hline & & $0.5 \mathrm{KIN}+1.52,4-\mathrm{D}$ & 60 & $67.4 \pm 4.7$ & Green \\
\hline & & $0.5 \mathrm{KIN}+2.02,4-\mathrm{D}$ & 60 & $72.2 \pm 4.6$ & Green \\
\hline & & $0.5 \mathrm{KIN}+2.52,4-\mathrm{D}$ & 60 & $78.8 \pm 5.1$ & Green \\
\hline & & $0.5 \mathrm{KIN}+3.02,4-\mathrm{D}$ & 60 & $73.5 \pm 4.1$ & Green \\
\hline & & $0.5 \mathrm{KIN}+3.52,4-\mathrm{D}$ & 60 & $56.8 \pm 4.9$ & Pale green \\
\hline & & $0.5 \mathrm{KIN}+4.02,4-\mathrm{D}$ & 60 & $54.4 \pm 5.1$ & Pale green \\
\hline & \multirow{7}{*}{$\begin{array}{l}\text { Epicarp } \\
\text { and hypoderm }\end{array}$} & $0.5 \mathrm{KIN}+1.0 \mathrm{NAA}$ & 60 & $45.8 \pm 4.7$ & Cream-white \\
\hline & & $0.5 \mathrm{KIN}+1.5 \mathrm{NAA}$ & 60 & $50.8 \pm 5.1$ & Cream-white \\
\hline & & $0.5 \mathrm{KIN}+2.0 \mathrm{NAA}$ & 60 & $51.2 \pm 4.6$ & Cream-white \\
\hline & & $0.5 \mathrm{KIN}+2.5 \mathrm{NAA}$ & 60 & $59.8 \pm 5.9$ & Violet \\
\hline & & $0.5 \mathrm{KIN}+3.0 \mathrm{NAA}$ & 60 & $64.3 \pm 5.6$ & Violet \\
\hline & & $0.5 \mathrm{KIN}+3.5 \mathrm{NAA}$ & 60 & $62.4 \pm 3.9$ & Violet \\
\hline & & $0.5 \mathrm{KIN}+4.0 \mathrm{NAA}$ & 60 & $53.6 \pm 4.9$ & Cream-pink \\
\hline
\end{tabular}

It should be noted that the combination $\mathrm{KIN}+2.4-\mathrm{D}$ is suitable to obtain more vigorous callus with only green colour. The callus obtained on the media with KIN+NAA was mostly friable and with a large range of colours, depending on the doses of NAA: white-cream $-1.0-20 \mathrm{mg} \times \mathrm{dm}^{-3}$; violet $2.5-3.5 \mathrm{mg} \times \mathrm{dm}^{-3}$; cream-pink $-4.0 \mathrm{mg} \times \mathrm{dm}^{-3}$.

Another objective was to determine the optimal dose of sucrose as the principal source of carbon for callusing in vitro. We tested a sucrose concentration of 10 to $60 \mathrm{~g} \times \mathrm{dm}^{-3}$ added to culture media supplemented with two combinations of growth regulators: $0.5 \mathrm{mg}$ $\times \mathrm{dm}^{-3} \mathrm{KIN}+3.02 .5 \mathrm{mg} \times \mathrm{dm}^{-3} \mathrm{NAA}$ and $0.5 \mathrm{mg} \times \mathrm{dm}^{-3}$ $\mathrm{KIN}+2.5 \mathrm{mg} \times \mathrm{dm}^{-3} 2,4-\mathrm{D}$ (Table 3 ). The observations showed that the value of sucrose dosage does not affect callus induction, but increasing the sucrose concentration stimulates the callus growth index in both growth regulator combinations and the highest value was found for the dose of $60 \mathrm{~g} \times \mathrm{dm}^{-3}$. It should be mentioned that for all sucrose doses the values of the growth index were higher for the medium with 2.4-D than for the one with NAA. 
Table 3

Effect of sucrose level on the callus growth index depending on growth regulator combinations

\begin{tabular}{ccc}
\hline \multirow{2}{*}{$\begin{array}{c}\text { Sucrose dose } \\
\left(\mathrm{g} \times \mathrm{dm}^{-3}\right)\end{array}$} & \multicolumn{2}{c}{ Callus growth index $(\%)$} \\
\cline { 2 - 3 } 10 & $26.4 \pm 4.0$ & $0.5 \mathrm{mg} \times \mathrm{dm}^{-3} \mathrm{KIN}+2.5 \mathrm{mg}^{2} \times \mathrm{dm}^{-3} 2,4-\mathrm{D}$ \\
\hline 20 & $29.1 \pm 3.2$ & $38.8 \pm 3.9$ \\
30 & $31.0 \pm 3.4$ & $40.1 \pm 4.0$ \\
40 & $44.6 \pm 4.9$ & $49.0 \pm 3.6$ \\
50 & $59.4 \pm 4.3$ & $67.8 \pm 5.0$ \\
60 & $64.3 \pm 5.1$ & $74.4 \pm 5.3$ \\
\hline
\end{tabular}

\section{Effect of light}

Light is an essential exogenous factor for morpho-functional development of plant cells and phenolic metabolism activity. The study investigated the effect of the following light regimes: natural photoperiod (day/night 16/8 h) as a control, continuous light, obscurity (7 days) followed by natural photoperiod; obscurity, red and ultraviolet light, depending on the growth regulator combinations of $0.5 \mathrm{mg} \times \mathrm{dm}^{-3} \mathrm{KIN}$
$+3.02 .5 \mathrm{mg} \times \mathrm{dm}^{-3} \mathrm{NAA}$ and $0.5 \mathrm{mg} \times \mathrm{dm}^{-3} \mathrm{KIN}+$ $2.5 \mathrm{mg} \times \mathrm{dm}^{-3} 2,4-\mathrm{D}$, on fruit callus intensity and some morphological characteristics of callus mass (Table 4). Explants inoculated on culture media supplemented with $0.5 \mathrm{mg} \times \mathrm{dm}^{-3} \mathrm{KIN}+2.5 \mathrm{mg} \times \mathrm{dm}^{-3} 2,4-\mathrm{D}$ initiate callusing earlier and the intensity of callusing is higher than on the ones with $0.5 \mathrm{mg} \times \mathrm{dm}^{-3} \mathrm{KIN}+3.02 .5 \mathrm{mg}$ $x \mathrm{dm}^{-3}$ NAA in all light regimes, except for obscurity (Table 4).

Table 4

Effect of light regime and growth regulator group of culture medium on A. melanocarpa (Michx.) Elliot carpocalogenesis

\begin{tabular}{|c|c|c|c|c|}
\hline Light regime & $\begin{array}{l}\text { Growth regulator } \\
\text { combinations }\end{array}$ & $\begin{array}{l}\text { Callus } \\
\text { inducing }\end{array}$ & $\begin{array}{l}\text { Intensity } \\
\text { of callusing }\end{array}$ & $\begin{array}{l}\text { Some morphological } \\
\text { characteristics of callus mass }\end{array}$ \\
\hline \multirow{2}{*}{$\begin{array}{l}\text { Natural photoperiod } \\
16 / 8 \mathrm{~h} \text { (control) }\end{array}$} & $\begin{array}{c}0.5 \mathrm{mg} \times \mathrm{dm}^{-3} \mathrm{KIN}+2.5 \\
\mathrm{mg} \times \mathrm{dm}^{-3} 2,4-\mathrm{D}\end{array}$ & at $5^{\text {th }}$ day & ++++ & Green, shiny, soft and viable callus. \\
\hline & $\begin{array}{c}0.5 \mathrm{mg} \times \mathrm{dm}^{-3} \mathrm{KIN}+3.0 \\
\mathrm{mg} \times \mathrm{dm}^{-3} \mathrm{NAA}\end{array}$ & at $6^{\text {th }}$ day & ++ & $\begin{array}{l}\text { Violet callus with cream sectors } \\
\text { and green islets. Non-viable callus. }\end{array}$ \\
\hline \multirow{2}{*}{$\begin{array}{l}\text { Continuous light } \\
\left(40-70 \mu \mathrm{M} \cdot \mathrm{m}^{-2} \cdot \mathrm{s}^{-1}\right)\end{array}$} & $\begin{array}{c}0.5 \mathrm{mg} \times \mathrm{dm}^{-3} \mathrm{KIN}+2.5 \\
\mathrm{mg} \times \mathrm{dm}^{-3} 2,4-\mathrm{D}\end{array}$ & at $4^{\text {th }}$ day & +++ & Green and mate callus with cream sectors. \\
\hline & $\begin{array}{c}0.5 \mathrm{mg} \times \mathrm{dm}^{-3} \mathrm{KIN}+3.0 \\
\mathrm{mg} \times \mathrm{dm}^{-3} \mathrm{NAA}\end{array}$ & at $5^{\text {th }}$ day & ++ & $\begin{array}{l}\text { Cream, mate and friable callus with violet } \\
\text { sectors. }\end{array}$ \\
\hline \multirow{2}{*}{$\begin{array}{l}\text { Obscurity (1-7 days), } \\
\text { followed by natural } \\
\text { photoperiod }\end{array}$} & $\begin{array}{c}0.5 \mathrm{mg} \times \mathrm{dm}^{-3} \mathrm{KIN}+2.5 \\
\mathrm{mg} \times \mathrm{dm}^{-3} 2,4-\mathrm{D}\end{array}$ & at $6^{\text {th }}$ day & +++++ & $\begin{array}{l}\text { First cream callus, then green, soft } \\
\text { and viable with cream and mate borders. }\end{array}$ \\
\hline & $\begin{array}{c}0.5 \mathrm{mg} \times \mathrm{dm}^{-3} \mathrm{KIN}+3.0 \\
\mathrm{mg} \times \mathrm{dm}^{-3} \mathrm{NAA}\end{array}$ & at $6^{\text {th }}$ day & + & $\begin{array}{l}\text { Cream, mate and friable callus } \\
\text { with pink islets. }\end{array}$ \\
\hline \multirow{2}{*}{ Obscurity } & $\begin{array}{c}0.5 \mathrm{mg} \times \mathrm{dm}^{-3} \mathrm{KIN}+2.5 \\
\mathrm{mg} \times \mathrm{dm}^{-3} 2,4-\mathrm{D}\end{array}$ & at $6^{\text {th }}$ day & ++ & $\begin{array}{l}\text { First gray callus, after } 12 \text { days } \\
\text { it becomes brown. }\end{array}$ \\
\hline & $\begin{array}{c}0.5 \mathrm{mg} \times \mathrm{dm}^{-3} \mathrm{KIN}+3.0 \\
\mathrm{mg} \times \mathrm{dm}^{-3} \mathrm{NAA}\end{array}$ & at $6^{\text {th }}$ day & ++ & $\begin{array}{l}\text { First gray callus, after } 10 \text { days } \\
\text { it becomes brown. }\end{array}$ \\
\hline \multirow{2}{*}{$\begin{array}{l}\text { Red light } \\
\left(80 \mu \mathrm{M} \cdot \mathrm{m}^{-2} \cdot \mathrm{s}^{-1}\right)\end{array}$} & $\begin{array}{c}0.5 \mathrm{mg} \times \mathrm{dm}^{-3} \mathrm{KIN}+2.5 \\
\mathrm{mg} \times \mathrm{dm}^{-3} 2,4-\mathrm{D}\end{array}$ & at $7^{\text {th }}$ day & +++ & $\begin{array}{l}\text { Cream, spongy and friable callus } \\
\text { with small green areas. }\end{array}$ \\
\hline & $\begin{array}{c}0.5 \mathrm{mg} \times \mathrm{dm}^{-3} \mathrm{KIN}+3.0 \\
\mathrm{mg} \times \mathrm{dm}^{-3} \mathrm{NAA}\end{array}$ & at $8^{\text {th }}$ day & ++++ & Violet, viable, shiny callus. \\
\hline \multirow{2}{*}{$\begin{array}{l}\text { Ultraviolet } \\
\left(30 \mu \mathrm{M} \cdot \mathrm{m}^{-2} \cdot \mathrm{s}^{-1}\right)\end{array}$} & $\begin{array}{c}0.5 \mathrm{mg} \times \mathrm{dm}^{-3} \mathrm{KIN}+2.5 \\
\mathrm{mg} \times \mathrm{dm}^{-3} 2,4-\mathrm{D}\end{array}$ & at $4^{\text {th }}$ day & +++++ & Green, viable, soft and shining callus \\
\hline & $\begin{array}{c}0.5 \mathrm{mg} \times \mathrm{dm}^{-3} \mathrm{KIN}+3.0 \\
\mathrm{mg} \times \mathrm{dm}^{-3} \mathrm{NAA}\end{array}$ & at $5^{\text {th }}$ day & +++ & Violet, friable and mate callus. \\
\hline
\end{tabular}


It has been shown that the presence of light is not required for callus induction, but the quality of light affects the time of induction (red light reduced this time, while ultraviolet radiation increases it by 1-2 days compared to the control) and light is mandatory and crucial to further development of fruit callus mass. The natural photoperiod is beneficial to start and develop green, shiny and viable callus mass on media with $0.5 \mathrm{mg} \times \mathrm{dm}^{-3} \mathrm{KIN}+2.5 \mathrm{mg} \times \mathrm{dm}^{-3} 2,4-\mathrm{D}$ and just to initiate callusing on that with $0.5 \mathrm{mg} \times \mathrm{dm}^{-3} \mathrm{KIN}$ $+3.0 \mathrm{mg} \times \mathrm{dm}^{-3} \mathrm{NAA}$. Red light facilitates the accumulation of violet viable and shiny callus on media with NAA. Ultraviolet radiation is beneficial for callusing in both growth regulator combinations. In all light regimes, the intensity of callusing was found to be higher on culture media with $0.5 \mathrm{mg} \times \mathrm{dm}^{-3} \mathrm{KIN}$ $+2.5 \mathrm{mg} \times \mathrm{dm}^{-3} 2,4-\mathrm{D}$ with one exception - under red light a higher intensity was found on media with $0.5 \mathrm{mg} \times \mathrm{dm}^{-3} \mathrm{KIN}+3.02 .5 \mathrm{mg} \times \mathrm{dm}^{-3}$ NAA.

\section{Callogenesis period and carpomass accumulation}

Many biotechnological experiments have found that the chokeberry callogenesis period is equal to 35-40 days, divided into four successive phases: lag, logarithmic growth, stationary and senescence. The biosynthesis processes and the mass accumulation capacity correlate with the callogenesis phase. In the lag phase (4-5 days duration), there were initial processes of adaptation and cell preparation to initiate proliferation. In the second phase - logarithmic growth (from the $6^{\text {th }}$ to the $18^{\text {th }}$ day), cell division was initiated at the end of the lag phase, resulting in intensive callusing and an increase in the number of cells in the $1^{\text {st }}$ half of the phase, but in the $2^{\text {nd }}$ half of this phase, at the same time, there was a reduction in cell division and cell expansion increased. The green color prevails in all carpomasses by the middle of the logarithmic growth phase, but at the end of this phase a difference in pigmentation appears, which correlates with the growth regulators added to the culture media: $\mathrm{KIN+2,4-D}$ - the prevalent color is green, while on KIN+NAAsupplemented media the cream and violet colors appear. The quantitative values increase very slightly during the $1^{\text {st }}$ part of the stationary phase, which lasts from the $18^{\text {th }}$ to the $34^{\text {th }}$ day. In this phase, the colors of callus mass become more intense, depending on the growth regulator combinations, from pale to intense green on KIN+2,4-D and from white-cream to violet on KIN+NAA. In the stationary phase, the maximum callus mass accumulation was observed for both combinations of growth regulators, but a higher value was found for the medium with 2,4-D compared to the one with NAA. In the senescence phase, a slight mass loss is observed. From the periphery to the centre, the callus mass becomes mate and friable and loses its viability; the processes are more intense on media with NAA than on those with 2,4-D.

A system of criteria was developed for describing and assessing polymorphism of fruit callus mass: growth vector (vertical, horizontal), degree of packing (compact, soft, spongy) and friability (disaggregated, not disaggregated), appearance of surface (mate, shine), and color (mono-, polychromatic, alternating colors). The growth regulator combinations with auxin and cytokinin conditioned the development of pigmented fruit callus mass: $1.5-3.0 \mathrm{mg} \times \mathrm{dm}^{-3} 2,4-\mathrm{D}+0.5 \mathrm{mg} \times \mathrm{dm}^{-3}$ KIN - green; $2.5-3.5 \mathrm{mg} \times \mathrm{dm}^{-3} \mathrm{NAA}+0.5 \mathrm{mg} \times \mathrm{dm}^{-3}$ KIN 2- violet; $4.0-5.0 \mathrm{mg} \times \mathrm{dm}^{-3}$ and $0.5 \mathrm{mg} \times \mathrm{dm}^{-3}$ KIN - cream-pink; and 1.0-2.0 $\mathrm{mg} \times \mathrm{dm}^{-3} \mathrm{NAA}+$ $0.5 \mathrm{mg} \times \mathrm{dm}^{-3} \mathrm{KIN}$ - cream-white (Fig. 2).

\section{Phenolic content}

\section{in pigmented biomass in vitro.}

Chokeberry fruits and fruit callus extracts were analyzed using the Folin-Ciocalteu method in order to determine their total polyphenol content (Table 5). The content of polyphenols in chokeberry fruits is 11892 $\mathrm{mg} / \mathrm{kg}^{-1}$. The polyphenol content in pigmented callus mass ranges from $3780 \mathrm{mg} / \mathrm{kg}^{-1}$ in the green mass, grown on culture media supplemented with $0.5 \mathrm{mg} \times$ $\mathrm{dm}^{-3} \mathrm{KIN}+1.0-4.0 \mathrm{mg} \times \mathrm{dm}^{-3} 2,4-\mathrm{D}$ growth regulator, to $12570 \mathrm{mg} / \mathrm{kg}^{-1}$ in the violet mass, grown on media with $0.5 \mathrm{mg} \times \mathrm{dm}^{-3} \mathrm{KIN}+1.0-4.0 \mathrm{mg} \times \mathrm{dm}^{-3}$ NAA growth regulators. It was found that in the pigmented mass (violet, cream-pink and cream-white), obtained on media supplemented with different doses of NAA+0.5 mg $x \mathrm{dm}^{-3} \mathrm{KIN}$, the polyphenol content was much higher than in the green callus mass, grown on those supplemented with the doses of 2,4-D+0.5 $\mathrm{mg} \times \mathrm{dm}^{-3} \mathrm{KIN}$.

The evaluation of alcoholic extracts from chokeberry fruits and in vitro-generated pigmented callus mass, in order to identify and determine the content of phenolic compounds by the CLIP method, found a quantitative variation in phenolic constituents. The concentrations and percent distribution of individual phenol compounds in the analyzed extracts are shown in Table 6. Chokeberry extracts and their biomass in vitro contained a mixture of different phenolic components and the most abundant was chlorogenic acid. The phenolic content in aronia extract $(25.474 \mu \mathrm{g} / \mathrm{ml})$ has an intermediate position: it is less than in the violet $(36.216$ $\mu \mathrm{g} / \mathrm{ml})$ and cream-pink $(34.024 \mu \mathrm{g} / \mathrm{ml})$ callus mass and more than in the cream-white $(20.300 \mu \mathrm{g} / \mathrm{ml})$ and green $(14.495 \mu \mathrm{g} / \mathrm{ml})$ callus mass. P-coumaric acid was not identified in chokeberry fruits, while it was identified only qualitatively in the green callus; quercetol was not found in the green callus mass, either. 


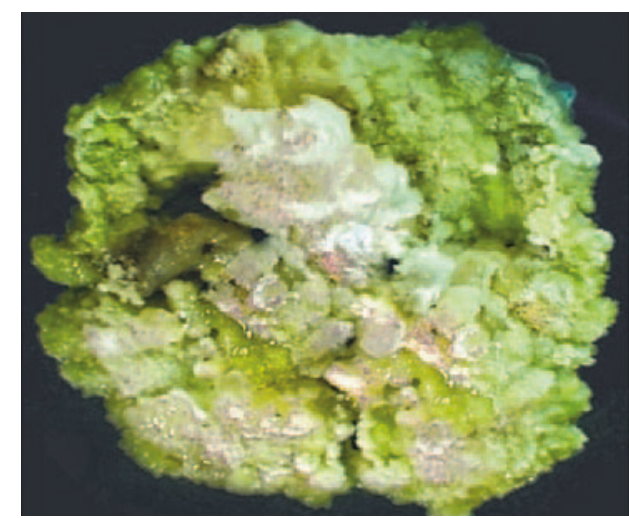

A. General aspect

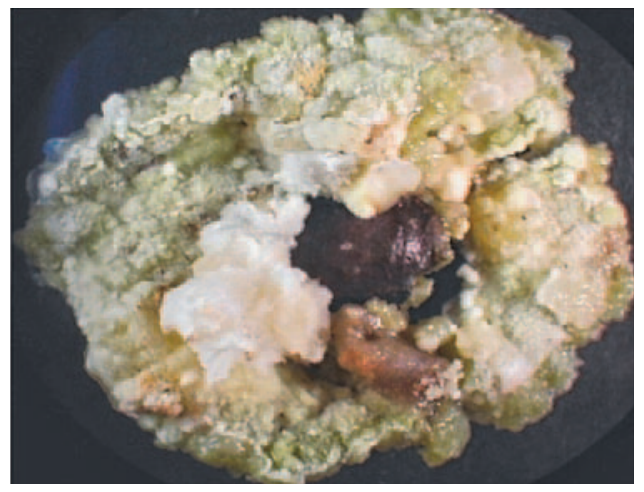

B. General aspect

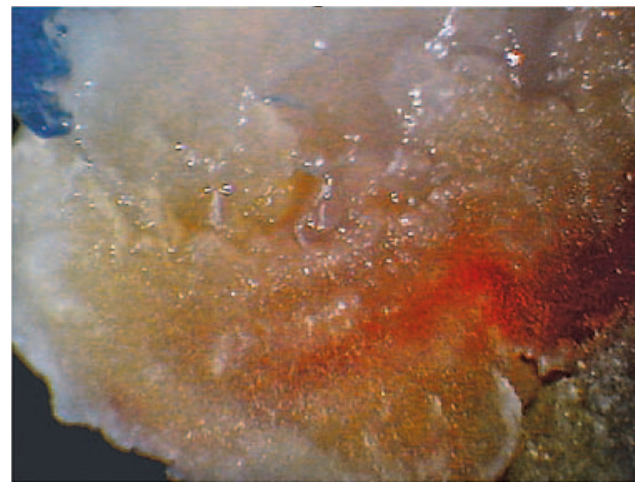

C. General aspect

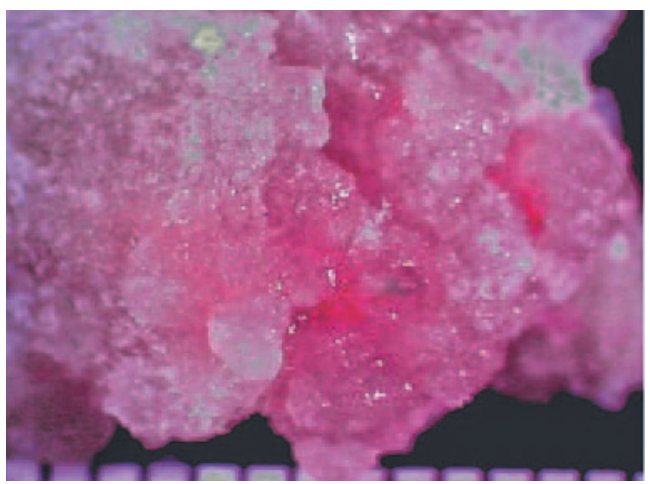

D. General aspect

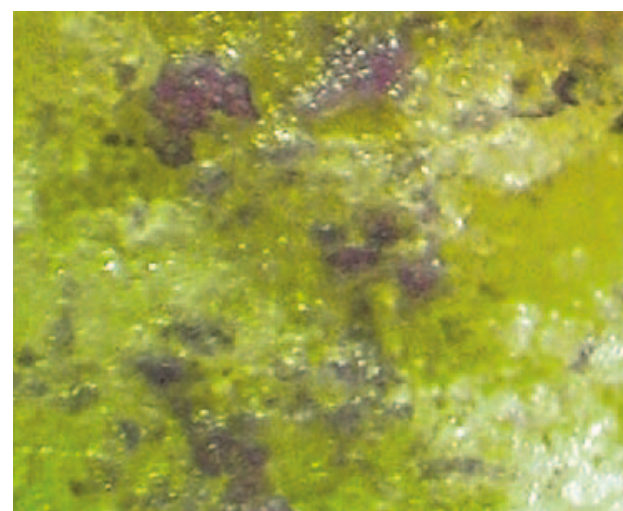

In section

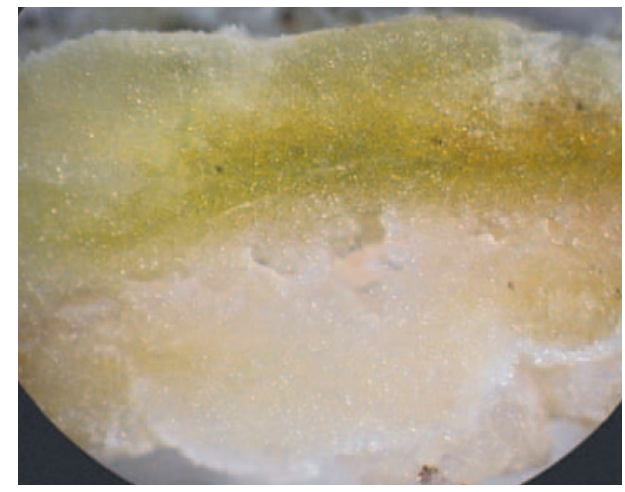

In section

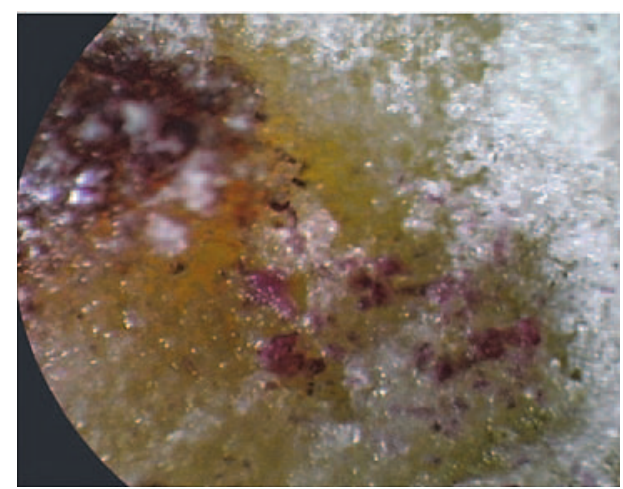

In section

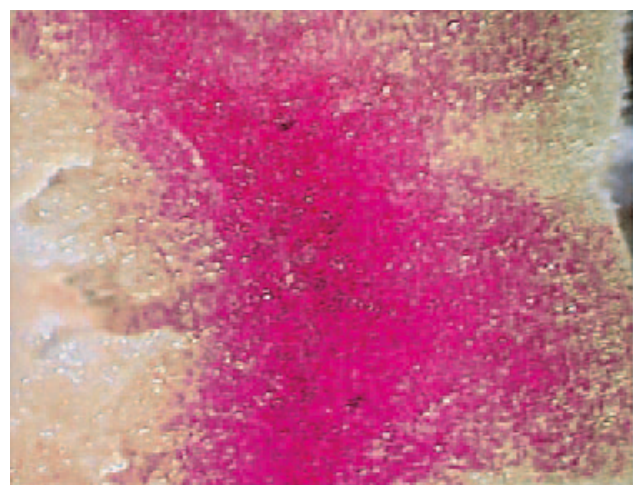

In section

Fig. 2. Pigmented carpomass, obtained on supplemented MS medium: A. Green $-2.0 \mathrm{mg} / 1$ 2, 4-D and $0.5 \mathrm{mg} / \mathrm{l} \mathrm{KIN}$; B. Creamwhite $-1.0-2.0 \mathrm{mg} / \mathrm{l} \mathrm{NAA}$ and $0.5 \mathrm{KIN}$; C. Cream-pink - 4.0-5.0 mg/l and 0.5 mg/l KIN; D. Violet - 2.5-3.5 mg/l ANA şi $0.5 \mathrm{mg} / \mathrm{l} \mathrm{KIN}$. 
Table 5

Total polyphenols in chokeberry fruit and callus mass in vitro extracts

\begin{tabular}{|c|c|c|}
\hline & Analyzed extracts & $\begin{array}{c}\text { Total polyphenols } \\
\left(\mathrm{mg} / \mathrm{kg}^{-1}\right)\end{array}$ \\
\hline \multirow{4}{*}{ 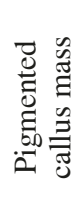 } & Violet & $12570 \pm 600$ \\
\hline & Cream-pink & $10910 \pm 320$ \\
\hline & Cream-white & $9170 \pm 300$ \\
\hline & Green & $3780 \pm 280$ \\
\hline \multicolumn{2}{|c|}{ Chokeberry fruit } & $11892 \pm 630$ \\
\hline
\end{tabular}

Table 6

Quantitative estimation of phenolic compounds in the chokeberry fruit and pigmented carpomass in vitro extracts

\begin{tabular}{|c|c|c|c|c|c|c|c|c|c|c|c|}
\hline \multirow{3}{*}{$\begin{array}{c}\text { Phenolic } \\
\text { Compounds }\end{array}$} & \multirow{3}{*}{$\begin{array}{c}\mathrm{Tr} \pm \mathrm{SD} \\
(\min )\end{array}$} & \multirow{2}{*}{\multicolumn{2}{|c|}{ Fruit }} & \multicolumn{8}{|c|}{ Pigmented callus mass } \\
\hline & & & & \multicolumn{2}{|c|}{ Violet } & \multicolumn{2}{|c|}{ Cream-pink } & \multicolumn{2}{|c|}{ Cream-white } & \multicolumn{2}{|c|}{ Green } \\
\hline & & $\mu \mathrm{g} / \mathrm{ml}$ & $\begin{array}{c}\% \\
\text { of total } \\
\text { phenolics }\end{array}$ & $\mu \mathrm{g} / \mathrm{ml}$ & $\begin{array}{c}\% \\
\text { of total } \\
\text { phenolics }\end{array}$ & $\mu \mathrm{g} / \mathrm{ml}$ & $\begin{array}{c}\% \\
\text { of total } \\
\text { phenolics }\end{array}$ & $\begin{array}{c}\mu \mathrm{g} / \\
\mathrm{ml}\end{array}$ & $\begin{array}{c}\% \\
\text { of total } \\
\text { phenolics }\end{array}$ & $\begin{array}{r}\mu \mathrm{g} / \\
\mathrm{ml}\end{array}$ & $\begin{array}{c}\% \\
\text { of total } \\
\text { phenolics }\end{array}$ \\
\hline Chlorogenic acid & $5.62 \pm 0.05$ & 18.31 & 71.91 & 21.037 & 58.08 & 19.682 & 57.84 & 12.90 & 63.55 & 10.636 & 73.37 \\
\hline P-coumaric acid & $8.70 \pm 0.08$ & A & A & 1.334 & 3.69 & 1.755 & 5.16 & 0.221 & 1.08 & Qv & Qv \\
\hline Hiperozide & $18.60 \pm 0.12$ & 2.016 & 7.93 & 3.638 & 10.06 & 3.571 & 10.49 & 0.927 & 4.56 & 0.409 & 2.83 \\
\hline Quercetrin & $23.00 \pm 0.13$ & 2.102 & 8.25 & 3.212 & 8.86 & 2.148 & 6.31 & 2.104 & 10.36 & 1.990 & 13.72 \\
\hline Isoquercitrin & $19.60 \pm 0.10$ & 1.947 & 7.64 & 5.795 & 16.02 & 5.030 & 14.78 & 3.411 & 16.80 & 1.254 & 8.65 \\
\hline Rutozide & $20.20 \pm 0.15$ & 0.948 & 3.72 & 0.948 & 2.62 & 1.393 & 4.09 & 0.429 & 2.11 & 0.206 & 1.43 \\
\hline Quercetol & $26.80 \pm 0.15$ & 0.142 & 0.55 & 0.252 & 0.69 & 0.445 & 1.33 & 0.307 & 1.51 & A & A \\
\hline Total & & 25.47 & 100 & 36.216 & 100 & 34.024 & 100 & 20.30 & 100 & 14.495 & 100 \\
\hline
\end{tabular}

Note: Overlapping in UV detection, only qualitative analysis possible using MS detection; A- Absent; Qv - only qualitative.

\section{DISCUSSION}

Succulent fruits of Aronia melanocarpa (Michx.) Elliot belong to the carpotype pommum with specific histo-anatomical traits and phenolic metabolism specialization and therefore they require special treatment and individual biomicrotechnology. The poтmит carpotype has a receptacular and appendicular origin and is characterized by histo-anatomical zonality. The zoality is a result of ovarian and extra-ovarian flower parts fusion and formation of pentacarpelar pericarp. The histo-anatomical zonation, tissue architecture, the distribution and location of primary and secondary metabolites play the main role in proliferative processes in vitro [10]. The determined histological zonality of fleshy chokeberry fruit pericap is the same as for almost all species from the Pomoideae subfamily, but with some cyto-biochemical characters which support the determination of the proliferative capacity in vitro. The structural and biochemical characteristics of chokeberry pericarp zonality correlate with successive ontomorphogenetic stages of fruit development [14]. This justified the need to determine the following: the optimal age of donor organ as explant; the histological nature of explant; the explant position in relation to culture media to induce callogenesis and biomass accumulation in vitro, called "carpoculture", by a group of researchers [9]. The proliferative reactions in vitro overcome and include the continuity of manifestation of the organ-specific pre-proliferative potential of pericarp cells $[9,15]$.

Chokeberry fruits are specialized in the biosynthesis of phenolic compounds [1]. Explants (all histogens) cut from the juvenile fruit (10-40 days after flowering) were characterized by high phenolic content, in particular in the cell wall as a result of adaptive reactions to protect the fine cell structure from high temperature and irradiation [7,9,10]. Massive accumulation of phenolic inclusions in the cell of the excised explants, is a result of the immediate defence reaction 
of fine in vitro cells [7,11], which formed a barrier against cell proliferation and led to the cell necrosis. Necrosis of explants taken from fruits at 70 days after flowering was provoked by vacuolated cells, which very easily cause the destruction of cellular integrity and phenolic compounds removal.

Our results show the high proliferative potency of explants at the middle age (50 and 60 days after flowering) of fruits, is possible due to balanced biochemical and cyto-anatomical parameters (the small size of cells, the low degree of vacuolization, moderate phenolic content, starch granule with energyability for early dedifferentiation). These features support in vitro cell viability and disclosure of proliferative potency. Similarly, several authors have mentioned the influence of explant nature and donor-fruit age, especially in the case of succulent pericarp, on callus initiation and accumulation [9,15-17]. Explant type and probably its anatomical structure seem to play a significant role in chokeberry callus initiation and accumulation. Variation in callus-forming ability of different explant types has been reported for many other succulent fruits $[15,16,18]$.

It is also generally accepted that due to the cyto-anatomic characteristics and role of histogen constituents, the hypoderm, as a constituent part of explants being in contact with media, promotes callus induction and the epicarp ensures its viability by performing a natural defense function, protecting hypodermic cells from negative preparation process for in vitro inoculation $[9,18]$. These two constituent parts (the epicarp with the hypoderm) of explant, by combining complementary functions and structural features, determine the maximum proliferative potency and callusing intensity [7]. We suggest that progressive callusing inside is reduced by the mechanical strength of culture media, so proliferation on the lateral incisions prevails, favoring horizontal biomass accumulation.

It should be noted that the auxin and cytokinin combination is suitable to induce callusing, stimulate callus proliferation and obtain vigorous biomass $[15,16,18]$. Sucrose was identified as the most efficient source of carbon necessary for vital activity of the cell, phenolic biosynthesis and proliferation in vitro [17]; the most suitable sucrose concentration for chokeberry cell growth and polyphenol formation was $60 \mathrm{~g} \times \mathrm{dm}^{-3}$.

The positive response of callogenesis on culture media with the doses of 2,4-D or NAA and KIN with sucrose as a source of carbon has already been reported for other species of plants $[10,18,19]$. These results are in agreement with other authors $[7,9,20]$ who showed that light is absolutely necessary for callus accumulation. According to several authors $[7,15,20]$, accu- mulating callus mass has certain characteristics, determined by cell biosynthesis processes that correlate with the callogenesis phase. The appearance of violet islets in biomass in the stationary phase shows the biosynthesis of phenolic metabolites, especially anthocyanins. Boris Matienco et al. [9] reported that a slight callus mass loss in the senescence phase of callogenesis is determined by cell dehydration, one characteristic of old plant cells.

According to other authors $[9,18,20]$, light regime and growth regulator balance of NM may inhibit or stimulate the structural and biosynthetic transformations in carpomass cells, thus modifying only the phase correlation length, but their sequence is maintained. The results of this study show that the callogenesis cycle consisting of four successive phases occurs in the chokeberry fruit, each with specific structural and biosynthetic characteristics serving as the basis for determining the optimal period for subcultivation on fresh culture medium to ensure the continuity and sustainability of fruit mass in vitro.

The phenolic compounds differ in carpomasses in vitro, according to their pigmentation determined by growth conditions in vitro (light regime, doses and type of growth regulators supplemented to media). The abovementioned factors were adequately used to enhance functional specialization of callus mass in the biosynthesis and storage of secondary metabolites, especially phenolic compounds. The data presented by other authors $[10,17,21,22]$ have also confirmed that the amount of total polyphenols and the content of phenolic compounds in biomass in vitro differ depending on doses and combinations of growth regulators. This suggests that the chemical composition of fruit biomasses in vitro can be manipulated by physical and nutritive factors.

\section{CONCLUSIONS}

Biological, physical and biotechnological conditions for callus initiation in succulent chokeberry fruit were optimized in this study. The basic reaction of fruit explants (epicarp and hypoderm), inoculated on media with combinations of $0.5 \mathrm{mg} \times \mathrm{dm}^{-3} \mathrm{KIN}$ $+1.0-4.0 \mathrm{mg} \times \mathrm{dm}^{-3}$ of NAA+60 $\mathrm{g} \times \mathrm{dm}^{-3}$ of sucrose and $0.5 \mathrm{mg} \times \mathrm{dm}^{-3} \mathrm{KIN}+1.0-4.0 \mathrm{mg} \times \mathrm{dm}^{-3}$ of 2,4-D + $60 \mathrm{~g} \times \mathrm{dm}^{-3}$ of sucrose, was callusing, but with different intensity, growth index and morphological characteristics, depending on the type and specific dose of growth regulator.

Fruit explants on media with the doses of 2,4-D growth regulator showed significantly higher callusing intensity than on media with the doses of NAA. Morphological variability of callus mass demonstrates the morphogenetic labiality of explant, which is an 
expression of genetic potential driven by the exogenous chemical agents.

The results of biotechnological testing show that culture media containing $0.5 \mathrm{mg} \times \mathrm{dm}^{-3} \mathrm{KIN}+$ $2.5 \mathrm{mg} \times \mathrm{dm}^{-3} 2$,4-D and natural photoperiod or obscurity, followed by natural photoperiod, were the best for callus initiation and mass accumulation and that with $0.5 \mathrm{mg} \times \mathrm{dm}^{-3} \mathrm{KIN}+3.0 \mathrm{mg} \times \mathrm{dm}^{-3} \mathrm{NAA}$, under red light was efficient for mass accumulation in vitro and enrichement of phenolic compounds.

The phenolic compounds differ in fruit callus mass in vitro, according to their pigmentation determined by growth conditions in vitro (light regime and doses and type of growth regulators). This suggests that the chemical composition of fruit callus mass in vitro can be manipulated by physical and nutritive factors.

\section{Authors' contributions}

T.C. - conducting experiments and writing the manuscript; A.N. - consultation concerning the application of the research method; S.O. and M.S. - contribution to discussion.

\section{REFERENCES}

1. Tanaka T, Tanaka A. Chemical components and characteristics of black chokeberry. J Jpn Soc Food Sci Technol Jpn. 2001; 48: 606-610.

2. Kokotkiewicz A, Jaremicz Z, Luczkiewicz M. Aronia plants: a review of traditional use, biological activities, and perspectives for modern medicine. J Med Food. 2010; 13(2): 255-269. http://dx.doi.org/10.1089/jmf. 2009.0062

3. Beattie J, Crozier A, Duthie G. Potential health benefits of berries. Curr Nutr Food Sci. 2005; 1(1): 71-86. http://dx.doi.org/10.2174/1573401052953294

4. Bell DR, Gochenaur K. Direct vasoactive and vasoprotective properties of anthocyanin-rich extracts. J Appl Physiol. 2006; 100(4): 1164-1170. http://dx.doi.org/ 10.1152/japplphysiol.00626.2005

5. Oszmiański J, Wojdylo A. Aronia melanocar$p a$ phenolics and their antioxidant activity. Eur Food Res Technol. 2005; 221(6): 809-813. http://dx.doi.org/10.1007/ s00217-005-0002-5

6. Valcheva-Kuzmanova SV, Belcheva A. Current knowledge of Aronia melanocarpa as a medicinal plant. Folia Med Plovdiv. 2006; 48(2): 11-17.

7. Calalb T. Aronia melanocarpa (Michx.) Elliot: (structura, biotehnologia, biochimia fructelor). Chişinău: Digital Hardware; 2010.

8. Lila MA. Valuable secondary products from in vitro culture. In: Gray D, Trigiano R, editors. Plant development and biotechnology. Boca Raton, FL: CRC Press; 2004. p. 285-289.
9. Matienco B, Brezeanu A, Maximova E, Marinescu M, Cogalniceanu G. Carpoculture in vitro. Non morphogenic pathway. Chişinău: Ştiința; 2004.

10. Matienco B, Zagornean E, Rotaru G, Osadcii V, Calalb T, Colesnicova L, et al. Principy strukturnyh preobrazovanij u rastenij. Chişinău: Ştiința; 1988.

11. Waterhouse A. Determination of total phenolics. Curr Protoc Food Anal Chem. 2001; 2(1): 1-8.

12. Toiu A, Vlase L, Oniga I, Tămaş M. HPLC-MS study of flavonoids from Viola arvensis and V. declinata (Violaceae). Rev Med Chir Soc Med Nat Iasi. 2007; 3(2 suppl): 103-107.

13. Rohrer JR, Robertson KR, Phipps JB. Variation in structure among fruits of Maloideae (Rosaceae). Am J Bot. 1991; 78(12): 1617-1635. http://dx.doi.org/ $10.2307 / 2444843$

14. Calalb T. Studiul histochimic şi biochimic al conținutului fenolic în ontomorfogeneza fructului Aronia melanocarpa (Michx.) Elliot. Elliot Bul Acad Ştiințe Mold Ştiințe Medicale. 2010; 1(24): 56-63.

15. Cogalniceanu G, Brezeanu A, Lupsea S, Matienco B. Factors that enhance cell proliferation and secondary metabolism (anthocyanin biosynthesis) in pericarp long-term callus culture of Vitis vinifera cv. Isabell. Acta Hort Bot Buc. 1999; 28: 303-317.

16. Harada H, Mukai H, Takagi T. Effects of explant age, growth regulators and carbohydrates on sugar accumulation in Citrus juice vesicles cultured in vitro. Sci Hortic. 2001; 90(1-2): 109-119. http://dx.doi.org/10.1016/S0304-4 238(00)00263-6

17. Suzuki H, Matsumoto T, Kisaki T, Nogu$\mathrm{chi}$ M. Influences of cultural conditions on polyphenol formation and growth of amacha cells (Hydrangea macrophylla Seringe var. Thunbergii Makino) and changes of polyphenol contents in leaves of amacha plant during growth. Agric Biol Chem. 1981; 45(5): 1067-1077. http://dx.doi. org/10.1271/bbb1961.45.1067

18. Sandhu R, Pandhir V, Das A, Gosal SS. Induction and proliferation of callus derived from fruits of different varieties of Capsicum annuum. J Plant Biochem Biotechnol. 2003; 12(2): 159-162. http://dx.doi.org/10.1007/B F03263179

19. Morini S, D'Onofrio C, Bellocchi G, Fisiche11 a M. Effect of 2,4-D and light quality on callus production and differentiation from in vitro cultured quince leaves. Plant Cell Tiss Organ Cult. 2000; 63(1): 47-55. http:// dx.doi.org/10.1023/A:1006456919590

20. Lut ov a L. Biotehnologia vyschih rasteniy. Sankt Petersburg: Izd-vo Sankt-Peterburgskogo Universiteta; 2003.

21. Floryanowicz-Czekalska K, Podsędek A, Wysokińska H. Chlorogenic acid in in vitro cultures of Eleutherococcus senticosus. Herba Pol. 2006; 52(1-2): $67-74$.

22. Freucht W, Treutter D, Christ E. Flavanols in grapevine: in vitro accumulation and defence reactions in shoots. Vitis. 1996; 35(3): 113-118. 


\section{Indukcja kalusa i akumulacja biomasy in vitro $\mathrm{z}$ owocu aronii (Aronia melanocarpa (Michx.) Elliot)}

\section{Streszczenie}

W przeprowadzonym badaniu najpierw określono następujące cechy: biologiczne (optymalny histogen jako explant oraz optymalny wiek owocu dawcy), biotechnologiczne (rodzaj, dawka i kombinacje regulatorów wzrostu dodanych do pożywek Murashige i Skooga oraz dawki sacharozy) i fizyczne (cykl świetlny), w celu indukcji kalusa i akumulacji biomasy in vitro $\mathrm{z}$ owocu aronii (Aronia melanocarpa (Michx.) Elliot). Okazało się, że o wiele łatwiej jest indukować kalus z eksplantów złożonych z egzokarpu i hipodermy wyciętych z owoców mających 50-60 dni po kwitnieniu. Określono rolę cyklu świetlnego oraz uzupełnienia podstawowej pożywki MS zróżnicowanymi dawkami regulatorów wzrostu; zastosowane regulatory wzrostu spowodowały powstanie kalusa o czterech zabarwieniach: fioletowym, kremowo-różowym, kremowo-białym i zielonym. Najlepszymi kombinacjami do rozmnażania kalusa $\mathrm{z}$ owocu były pożywki zawierające $0,2-2,5 \mathrm{mg} \times \mathrm{dm}^{-3} 2,4-\mathrm{D}+0,5 \mathrm{mg} \times \mathrm{dm}^{-3} \mathrm{KIN}+60 \mathrm{~g} \times$ $\mathrm{dm}^{-3}$ sacharozy, podczas gdy dla akumulacji biomasy owocu wzbogaconej o substancje fenolowe, pożywki zawierające $2,5-3,5 \mathrm{mg} \times \mathrm{dm}^{-3} \mathrm{NAA}+0,5 \mathrm{mg} \times \mathrm{dm}^{-3}$ $\mathrm{KIN}+60 \mathrm{~g} \times \mathrm{dm}^{-3}$ sacharozy. Na podstawie analiz chemicznych związków fenolowych przeprowadzonych przy użyciu HPLC w połączeniu z metodą spektrometrii mas oznaczono jakościowo oraz ilościowo kwas chlorogenowy, hiperozyd, kwercetrynę, izokwercetrynę i rutozyd w zabarwionym kalusie i owocach; wyjątkiem jest kwas p-kumarowy, który był obecny wyłącznie jakościowo w zielonej masie kalusa i nieobecny w owocach, oraz kwercetrol, który był nieobecny w zielonym kalusie.

Handling Editor: Elżbieta Weryszko-Chmielewska

This is an Open Access digital version of the article distributed under the terms of the Creative Commons Attribution 3.0 License (creativecommons.org/licenses/by/3.0/), which permits redistribution, commercial and non-commercial, provided that the article is properly cited.

(CThe Author(s) 2014 Published by Polish Botanical Society 